\title{
Well Differentiated Ovarian Sertoli-Leydig Cell Tumor
}

National Cancer Institute

\section{Source}

National Cancer Institute. Well Differentiated Ovarian Sertoli-Leydig Cell Tumor. NCI

Thesaurus. Code C4209.

A Sertoli-Leydig tumor of the ovary characterized by the presence of Sertoli cells in tubules without evidence of significant nuclear atypia or mitotic activity. Primitive gonadal stromal cells are not present. It usually follows a benign clinical course. 